\title{
Effects of plastic stenting in commom bile duct of rats. A quantitative reaction analysis using collagen and elastin morphometry ${ }^{1}$
}

\author{
Efeitos de prótese plástica em hepatocolédoco de ratos. Uma análise quantitativa utilizando \\ morfometria do colágeno e elastina
}

\author{
Everson Luiz de Almeida Artifon', Fabio Pinatel Lopasso"I, Gustavo Brazuna Moura'II, Fernando Augusto Mardiros Herbella \\ Fernandes $^{\mathrm{IV}}$, Paulo Sakai ${ }^{\mathrm{V}}$, Flair José Carrilho ${ }^{\mathrm{VI}}$, Elia Tamaso Espin Garcia Caldini ${ }^{\mathrm{VII}}$, Orlando de Castro e Silva Junior ${ }^{\mathrm{VIII}}$ \\ ${ }^{I} \mathrm{PhD}$, Assistant Professor, Department of Gastroenterology, Faculty of Medicine, USP, São Paulo, Brazil.

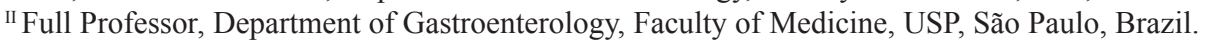 \\ III Resident, Department of Gastroenterology, Faculty of Medicine, USP, São Paulo, Brazil. \\ ${ }^{\text {IV }} \mathrm{PhD}$, Assistant Professor, Department of Gastroenterology, São Paulo Federal School of Medicine, São Paulo, Brazil. \\ ${ }^{v}$ Full Professor, Department of Gastroenterology, Faculty of Medicine, USP, São Paulo, Brazil. \\ ${ }^{V I}$ Full Professor, Department of Gastroenterology, Faculty of Medicine, USP, São Paulo, Brazil. \\ ${ }^{V I I}$ Full Professor, Department of Pathology, Faculty of Medicine, USP, São Paulo, Brazil. \\ VIII Full Professor, Department of Anatomy and Surgery, Faculty of Medicine of Ribeirao Preto, USP, São Paulo, Brazil.
}

\begin{abstract}
Purpose: To evaluate the effects of biliary stenting in rats through analysis of collagen and elastin deposition in the bile ducts. Methods: Twenty male rats underwent midline laparotomy, duodenotomy and transampullary stenting of the common bile duct with a 22Fr plastic stent. Animals were randomized in 4 groups, with 5 components in each: (I) control, (II) biliary stenting for 7 days, (III) biliary stenting for 14 days, and (IV) biliary stenting for 30 days. Sections of the common bile duct were stained using Hematoxylin Eosin; Sirius Red to quantitate the amount of collagen present; and Weigert's Resorcin-fuchsin to quantitate the amount of elastin present. Results: The percentage of area stained for collagen was $13.4 ; 21.5 ; 29.5$ and 32.8, for groups I to IV, respectively. The percentage of area stained for elastin fibers was 7.0; 5.2; 4.0 and 2.9, for groups I to IV, respectively. Collagen/Elastin ratio was 2.4; 5.1 ; 11.0 and 14.4 for groups I to IV, respectively. Conclusions: The biliary stenting leads to collagen and elastin deposition in the bile ducts; and collagen deposition and collagen/elastin ratio are proportional to the period of stenting.
\end{abstract}

Key words: Prostheses and Implants. Collagen. Elastin. Common Bile Duct. Rats.

\section{RESUMO}

Objetivo: Avaliar os efeitos da colocação de prótese biliar em ratos, analisando a deposição de colágeno e elastina no hepatocolédoco. Métodos: Vinte ratos machos foram submetidos à laparotomia mediana, duodenotomia e colocação transpapilar de uma prótese plástica 22Fr no hepatocolédoco. Os animais foram randomizados em 4 grupos, com cinco componentes cada: (I) controle, (II) prótese biliar por 7 dias, (III) prótese biliar durante 14 dias e (IV) prótese biliar por 30 dias. Cortes do hepatocolédoco foram corados com Hematoxilina Eosina; Sirius Red para quantificar o colágeno; e Resorcina-fucsina de Weigert para quantificar a elastina. Resultados: A porcentagem de área corada para colágeno foi de 13,$4 ; 21,5 ; 29,5$ e 32,8 para os grupos I a IV, respectivamente. A porcentagem de área corada para fibras de elastina foi de 7,0; 5,2; 4,0 e 2,9, para os grupos I a IV, respectivamente. A razão colágeno / elastina foi de 2,4, 5,1, 11,0 e 14,4 para os grupos I a IV, respectivamente. Conclusões: O implante da prótese biliar leva à deposição de colágeno e elastina nos ductos biliares; e a deposição de colágeno e a relação colágeno / elastina são proporcionais ao tempo de permanência da prótese.

Descritores: Próteses e Implantes. Colágeno. Elastina. Ducto Colédoco. Ratos.

${ }^{1}$ Research performed at the Laboratory, Department of Clinical Gastroenterology, Faculty of Medicine, University of São Paulo (USP), Brazil.

\section{Introduction}

Bile duct stenting is a common procedure for drainage of biliary obstructions due to malignant or benign causes. Surgically placed biliary drains predate the earliest report of endoscopically inserted biliary drains in $1989^{1}$. Little is known about the short and long term effects of such prosthesis on bile ducts and adjacent organs. Changes related to such stents may be of relevance especially when biliary stents are placed for benign and potentially curable conditions. Karsten et $a .^{2}$ reported increased bacterial colonization, fibrosis and reactive hyperplasia in extrahepatic bile ducts of dogs in contact with the plastic stent system. In 2000, Dunkin et al. ${ }^{3}$ performed histological analysis of liver and pancreatic tissue, and noted chronic inflammatory changes in the 
bile ducts system, but none in the liver or pancreas. Wagholikar et $a l .{ }^{4}$ have previously reported significant morphological and fibroproliferative inflammatory changes at pancreaticoduodenectomy in bile ducts of 31 patients who had previously undergone bile duct stenting, making surgical excision something more difficult. Others studies have also reported that these stents lead to difficulty in surgical dissection due the local tissue reaction ${ }^{5,6}$.

This study aims to evaluate the effects of biliary stenting in rats through analysis of collagen and elastin deposition in the bile ducts, and the macroscopic and microscopic changes in the pancreatic and hepatic parenchyma.

\section{Methods}

Twenty Wistar male rats, weighing between 280 to $320 \mathrm{~g}$, were randomized in 4 groups: (I) control ( $n=5)$, (II) biliary stenting for 7 days $(n=5)$, (III) biliary stenting for 14 days $(n=5)$, and (IV) biliary stenting for 30 days $(n=5)$.

Animals were anesthetized with intraperitoneal ketamine cloridrate $10 \%(100 \mathrm{ml} / \mathrm{Kg})$ and xylazine $2 \%(100 \mathrm{ml} / \mathrm{Kg})$. All groups underwent a midline laparotomy, duodenotomy and transampullary stenting of the common bile duct with a $22 \mathrm{~F}$ plastic stent. Blood loss and trauma to the viscera were kept to a minimum. Principles of antisepsis were respected during the procedure.

In group I, the stent was immediately removed, acting as control. In groups II, III and IV, the stent was removed 7, 14 and 30 days after the procedure, respectively.

At the designated time, animals were euthanatized and en-bloc resection of the liver, bile ducts, pancreas and duodenum performed (Figure 1). The bloc was fixed in 10\% formalin.

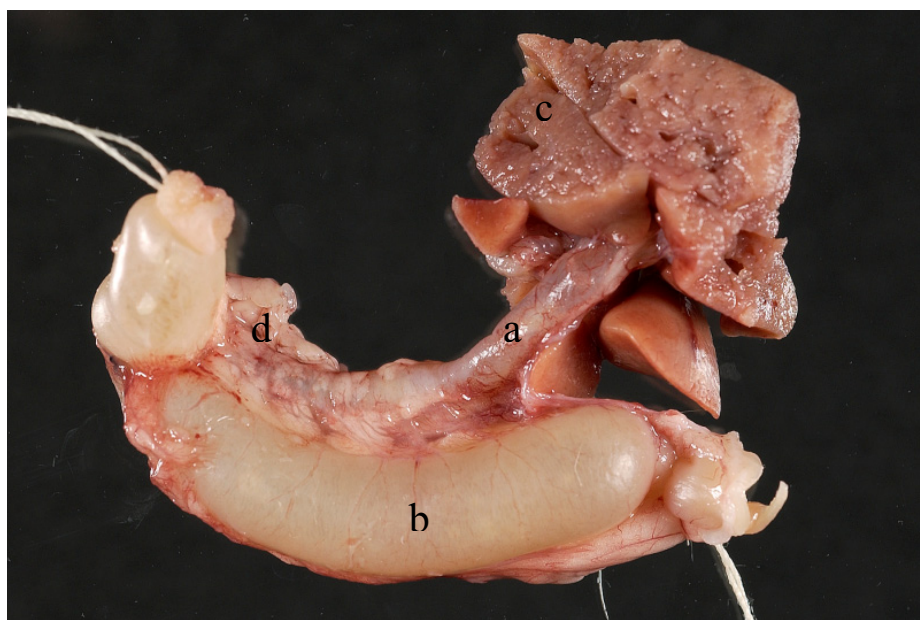

FIGURE 1 - Image block formalized surgical specimen obtained where we observe the dilated bile duct and plastic stent inside (a), duodenum (b), liver (c) and pancreas (d).

\section{Macroscopic changes}

Adhesions between surrounding viscera and the biliary system were recorded.

\section{Microscopic analysis}

Sections of the common bile duct were properly processed for hematoxylin and eosin stain, and subsequently evaluated by an experienced pathologist. Sirius red staining was performed to quantitate the amount of collagen present and Weigert's Resorcin-fuchsin staining was performed to quantitate the amount of elastin present. Computerized digital analysis was used to quantify the area of staining in each slide. Digital images (using Nikon DXM1200F a digital video camera attached to the Nikon Eclipse E600 microscope) were obtained of each histological section, at 20x magnification for collagen analysis and 40x for elastin analysis. Digitized images were processed using Nikon ACT-1 (version 2.62 2000) and Adobe Photoshop 7.0. Quantitative analysis was done by Image J Software, developed by National Institute of Health.

\section{Statistics}

The data were arranged in the SPSS statistical system and values were expressed as percentage \pm standard deviation $[95 \%$ confidence interval]. Tukey test was used for comparison among groups. A value of $p<0.05$ was considered significant.

\section{Ethics}

The study was approved by the local ethical committee. All procedures followed the regulations of the Brazilian College for Animal Experimentation and the US National Institute of Health-Guide for care and use of laboratory animals guidelines.

\section{Results}

\section{Macroscopic analysis}

Macroscopic adhesions between surrounding viscera and the biliary system were present in 2 rats: 1 in group III and 1 in group IV and it was seen in the area of the duodenotomy to place the transpapillary plastic stent. It was not demonstrated adherences between the adjacent visceras and common bile duct.

\section{Microscopic analysis}

\section{Histopathologic}

In Group I there were solitary ulcers in the bile duct epithelium but no inflammatory cells. In Group II solitary superficial ulcerations were present mainly at the the middle portion of the bile duct. The submucosal layer showed slight thickening due vascular congestion and perivascular edema, presence of mast cells, eosinophils and elongated cells with round nucleus dispersed. In Group III there was extensive desquamation of the epithelium with re-epithelization in some areas and the bile duct wall was approximately 3 fold thickened. There was flattening of the epithelium with intense focal epithelial reactivity with increase in stratified layers. There was an intermediate increase in inflammatory cells with moderate number of fusiform appearing cells, intense mitotic activity with pyknotic nuclei. There was mild edema and formation of saculos de Beale. In Group IV, epithelium of difficult characterization, presenting areas of reactivity with purely cuboid cells and round nuclei. The bile duct wall was thickened around 3-4 times that normal. Large quantity of fusiform cells with small nucleus in the submucosa. Minimal inflammatory cells, with 
predominance of lymphocytes and macrophages. Focal intestinal metaplasia in some saculos de Beale (presence of caliciforms cells). Absence of submucosal edema.

Group I did not reveal any abnormalities in the liver. In the others groups there was the presence of inflammatory infiltrate comprising of eosinophils, macrophages and lymphocytes, compatible with mild cholangitis along with focal dilation of intrahepatic ducts. These results increased in mild and gradual in group II to IV. There was absence of any histopathological changes in pancreas (Figures 2 and 3).

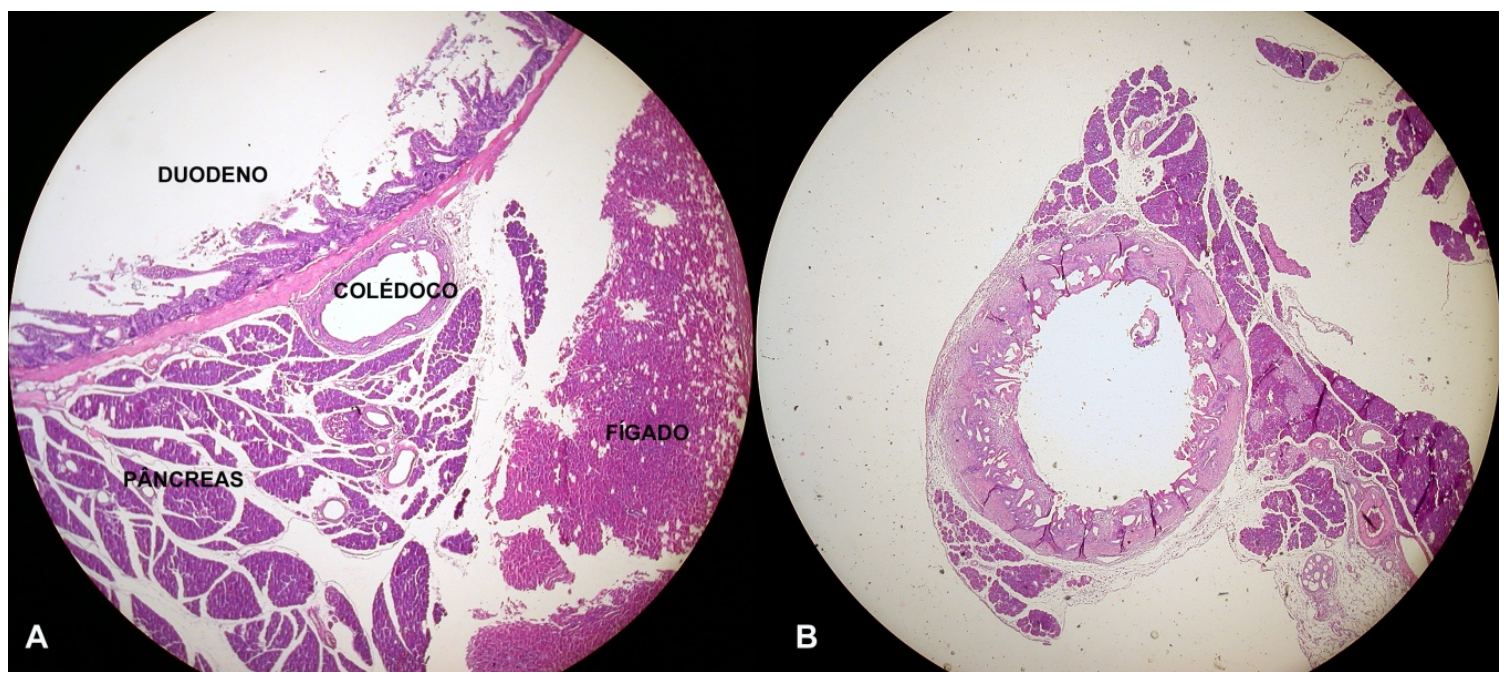

FIGURE 2 - A. Microscopic large increase of commom bile duct, pancreas and liver of control rat. B. Microscopic image with a small increase in commom bile duct after the use of plastic biliary stent, highlighting the findings of wall thickening, presence of inflammatory cells and fibrocytes

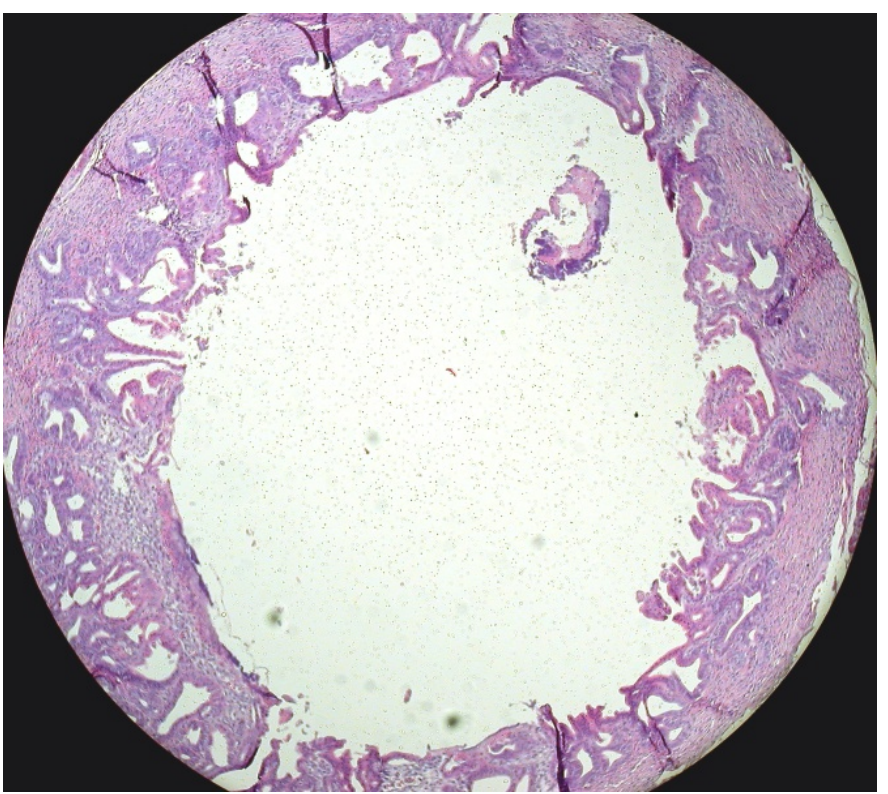

FIGURE 3 - Microscopic image with a large increase in commom bile duct with evidence of inflammatory reaction after the use of biliary stent (Beale's outpouchings)
Collagen and elastic fiber the ratio of collagen fiber/ elastin deposition

There was no difference in the amount of collagen deposition or elastic fiber in the 4 groups of rats. There was increasingly greater amount of collagen deposition in groups I, II and III, being similar in group III and IV. There was no significant difference in the elastin fiber in the 4 groups. The ratio of collagen/ elastic fiber, between different groups showed values significantly higher in group IV when compared with control (group I) and group II.

The percentage of area stained for collagen was $13.4 \pm 5.2$

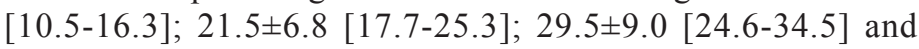
$32.8 \pm 6.1$ [29.4-36.2], for groups I to IV, respectively. Collagen staining was higher for group II compared to group I $(p=0.014)$ and higher for group III compared to group II $(p=0.015)$. There was no difference in collagen staining between group IV and III ( $\mathrm{p}=0.585)$ (Figure 4).

The percentage of area stained for elastin fibers was 7.0 \pm 3.1 [5.3-8.7]; 5.2 \pm 2.4 [3.9-6.5]; $4.0 \pm 2.3$ [2.7-5.2]; and 2.9 \pm 1.4 [2.1-3.6], for groups I to IV, respectively. Elastin staining was higher for group III compared to group I $(p=0.008)$; IV compared to I $(p<0,001)$, and IV compared to III $(p=0.05)$. There was no difference in elastin staining between groups I and II $(\mathrm{p}=0.194)$; II and III ( $\mathrm{p}=0.537)$; and III and IV $(\mathrm{p}=0.584)$ (Figure 5). Collagen/Elastin ratio was $2.4 ; 5.1 ; 11.0$; and 14.4 for groups I to $\mathrm{IV}$, respectively. 

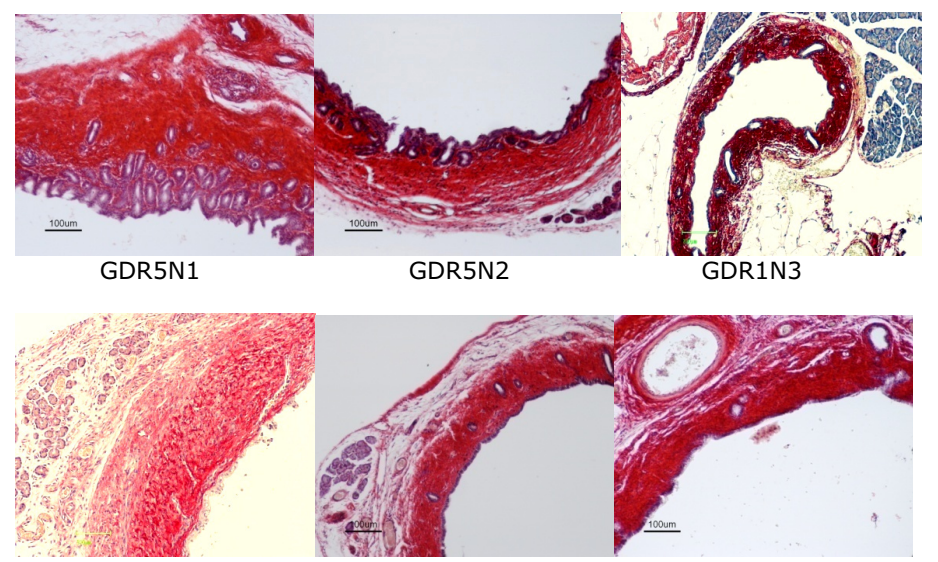

GCR4N1
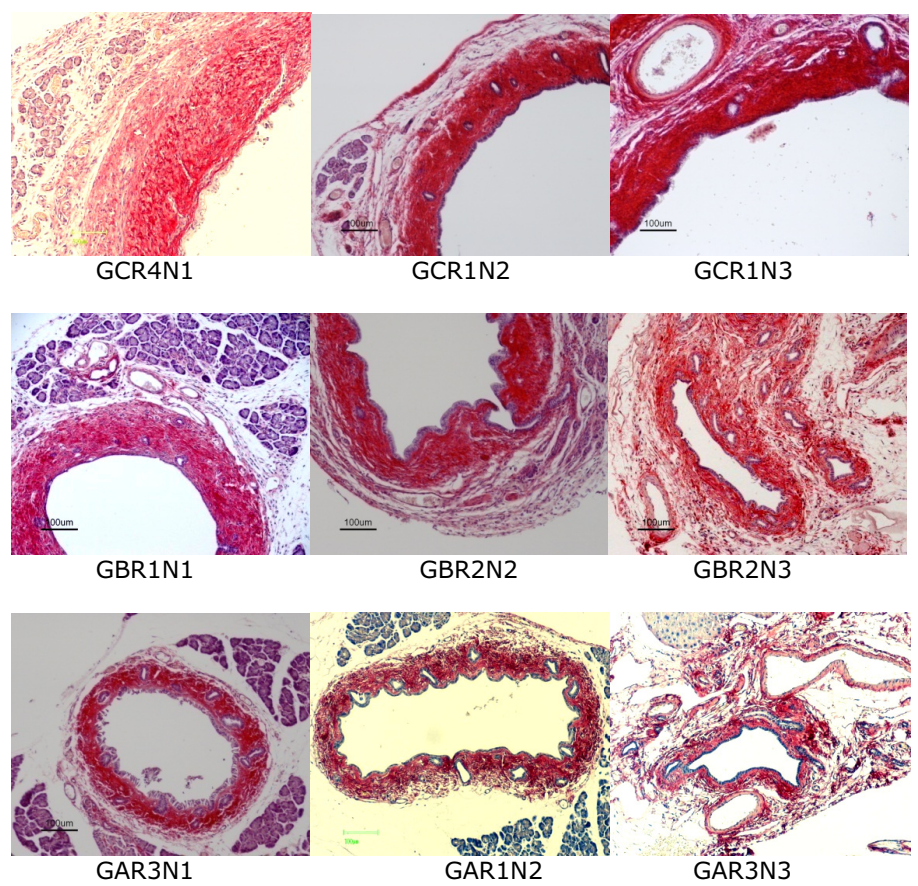

FIGURE 4 - Sections of the common bile duct stained with the picrosirius-hematoxylin (PSH) demonstrating the progressive increase in fibrillar collagen deposition in the bile duct observed in the groups A, B, C and D. Note the similar characteristics of deposition in different levels of the common bile duct of rats from the same group

\section{Discussion}

Clinical series of patients submitted to biliary stenting Karsten et al. ${ }^{2}$ reported that patients with biliary obstruction, who underwent drainage by stenting had intense chronic inflammatory reaction and correlating histological changes in the bile duct in proximity to the lesion with irregular destruction of the mucosal surface and intense fibrotic reaction in the submucosa.

There are evidences indicating relationship between bile with bacteria and the frequency of postop complications ${ }^{7,8}$. Retrospective study has shown that patients with bacteria in the bile are epidemiologically similar to the patients with high risk for postop infections (15 to $20 \%)^{7}$. Although, the incidence of bacteria in the bile of the patients with jaundice due to pancreatic head Ca varies from 16 to $25 \%$ without endoscopic drainage and $1-3 \%$ with drainage by plastic biliary stent $t^{2,7,8}$. With this, can understand that the inflammatory thickening of the bile duct wall due to the infection represent one of the most important factors in postop complications of patients who underwent prior endoscopic drainage. Dunkin et al. ${ }^{3}$ relates that the reactive inflammatory process due to biliary stent happens in a way to completely involve the extrahepatic biliary tree, including the cystic duct and the commom bile duct. In our study it occurs mainly in the bile duct in contact with the stent.

Karsten et al. ${ }^{9}$, in study with dogs, showed that the
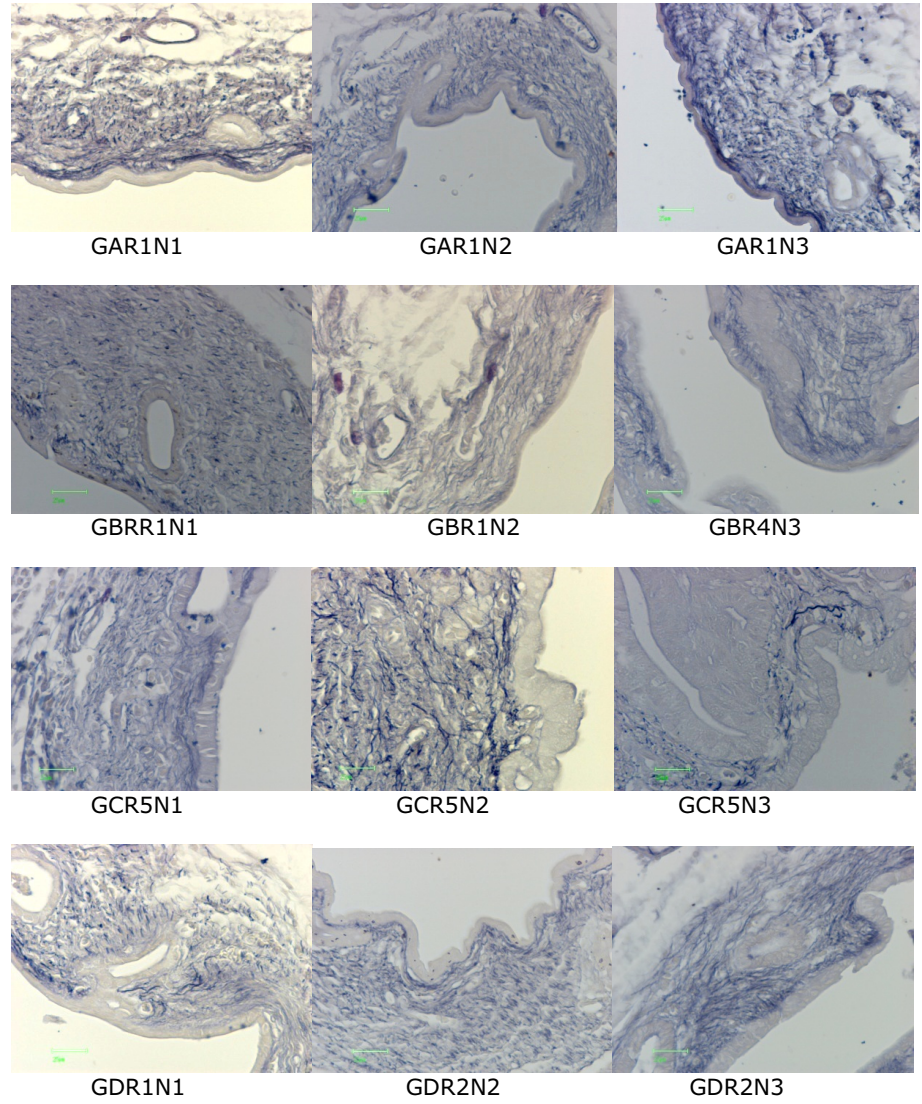

FIGURE 5 - Sections of the common bile duct stained with resorcinfuchsin-oxidized (RFO) showing a progressive decrease in the deposition of elastic fibers in groups A, B, C and D. Note the similar characteristics of deposition in different levels of the common bile duct of rats from the same group

insertion of a stent in normal or obstructed bile duct induced extensive inflammation of the extra-hepatic biliary duct and the bile colonization, which persisted for two months after removal of the prosthesis. Furthermore, the occurrence of intra-abdominal adhesions and dehiscence of anastomosis surgery was greater in the group with biliary stent. There is evidence that linked the rise of microorganisms in biliary tract and postoperative complications, showing rates of infection from 15 to $20 \%{ }^{9}$.

Carrasco et al. ${ }^{10}$ found similar histological changes in the bile ducts of dogs drained with self expandable metal stent.

While the mechanisms underlying these inflammatory changes is not known, these may be a result of: ${ }^{11,12}$ a) friction of the stent against the biliary epithelium permitting continuous solution and the immunoreactive elements diluted in the bile, provoke immunologic cascade; $b$ ) the pressure of the stent by direct contact with the epithelium resulting in local ischemia with formation of microulcers; c) reflux of unsterile duodenal contents from the duodenal lumen into the bile duct. Karsten et al. ${ }^{9}$ did important study in dogs where it was verified that transpapillary stent caused bacterial contamination of bile and intense chronic inflammation causing thickening of the bile duct that was previously normal and also in the obstructed part. Other investigators have demonstrated that these inflammatory changes may persist even following removal of the biliary stent ${ }^{13-18}$. It should be considered that the persistence 
of chronic inflammatory effect and of fibroblastic reaction in the bile duct in which the bile stent has already been removed occurred due to bacteria in the bile at the time of endoscopic drainage.

Regarding the type of material of the prostheses, both plastic, metal and, more recently, the biodegradable not differ in terms of histology, bile duct or serum determinations, and the findings of previous studies of the latter with low or no toxicity ${ }^{19}$.

In the present study was demonstrated that more strongly reaction of collagen and relationship between elastin and collagen occurred at the 15 days, meaning hystologic events in the lumen and mainly in the extrahepatic biliary wall. Then, we should bear in mind that the difficulties problems related to the surgery can be avoid if the patient underwent to surgery procedure until 2 weeks after the stent had left in place. After this critical period, the wall become very tight and the inflammatory process could determine techniques problems during surgery procedure.

We verified in our study that the collagen deposition occurred in inverse proportion of the elastic fibers, and this probably resulted in more rigidity of the hepatobiliary duct that, due to the new reactive histologic structure, would permit the creation of the anastomosis with more risk of fistulae and dehiscense.

We conclude that: (a) biliary stenting leads to collagen and elastin deposition in the bile ducts, and (b) collagen deposition and collagen/elastin ratio are directly proportional to the period of stenting.

\section{Conclusion}

Biliary stenting leads to collagen and elastin deposition in the bile ducts, and collagen deposition and collagen/elastin ratio are directly proportional to the period of stenting.

\section{References}

1. Costamagna G, Crucitti F. Endoscopic internal biliary drainage. Rays. 1989;14(2):115-21.

2. Karsten TM, Coene PP, van Gulik TM, Bosma A, van Marle J, James J, Lygidakis NJ, Klopper PJ, van der Heyde MN. Morphologic changes of extrahepatic bile ducts during obstruction and subsequent decompression by endoprostheses. Surgery. 1992;111:562-8.

3. Dunkin BJ, Marks JM, Singh J, Lash RH, Ponsky JL. Short-term endobiliary stenting results in chronic inflammation the porcine extrahepatic system. Surg Laparosc Endosc Percutan Tech. 2000;10(5):275-7. 4. Wagholikar GD, Sikora SS, Pandey R, Prasad KK, Kumar A, Saxena R, Kapoor VK. Morphological changes in bile ducts following preoperative biliary stenting. Indian J Gastroenterol. 2003;22(5):166-9.

5. Diaz SG, Cansino CT. Choledochal prosthesis and anti-inflammatory hormones. Experimental study. Lyon Chir. 1996;62(2):229-36.

6. Sherman S, Alvarez C, Robert M, Ashley SW, Reber HA, Lehman GA. Polyethylene pancreatic duct stent-induced changes in the normal dog pancreas. Gastrointest Endosc. 2001;39(5):658-64.

7. Reighley MRB, Flinn R, Williams JA. Multivariate analysis of clinical and operative findings associated with biliary sepsis. Br J Surg. 1976;63:258-61.

8. Cox JL, Helfrich LR, Pass HI, Osterhaut S, Shingleton WW. The relantionship between biliary tract infections and postoperative complications. Surgery. 1978;146:233-6.

9. Karsten TM, Davids PH, van Gulik TM, Bosma A, Tytgat GN, Klopper PJ, van der Hyde MN. Effects of biliary endoprostheses on the extrahepatic bile ducts in relation to subsequent operation of the biliary tract. J Am Coll Surg. 1994;178(4):343-52.

10. Carrasco CH, Wallace S, Charnsangavej C, Richli W, Wright KC, Fanning T, Gianturco C. Expandable biliary endoprosthesis: an experimental study. Am J Roentgenol. 1985;145:1279-81.

11. Raper SE, Baker ME, Jones AL, Way LW. Anatomical correlates of bacterial cholangiovenous reflux. Surgery. 1989;105:352-9.

12. Deitch EA, Sittig K, Li M, Berg R, Specian RD. Obstructive jaundice promotes bacterial translocation from the gut. Am J Surg. 1990;159:79-84. 13. Haber MH. Histopathological changes in the obstructed common bile duct. J Pathol Bacteriol. 1962;84:413-20.

14. Huang T, Bass JA, Williams RD. The significance of biliary pressure in cholangitis. Arch Surg. 1969;98:629-32.

15. Goldman LD, Steer ML, Silen W. Recurrent cholangitis after biliary surgery. Am J Surg. 1983;145:450-4.

16. Huibregtse K, Katon RM, Coene PP, Tytgat GNJ. Endoscopic palliative treatment in pancreatic cancer. Gastrointest Endosc. 1986;32:334-8.

17. James J, Fredericks WN, van Noorden CJF. Early changes in cholestatic livers as a consequence of hepatic duct carcinoma: a histological and histochemical exploration. Semin Liver Dis. 1990;10:91-101.

18. Dunkin BJ, Marks JM, Singh J, Lash RH, Ponsky JL. Short-term endobiliary stenting results in chronic inflammation of the porcine extrahepatic biliary system. Surg Laparosc Endosc Percutan Tech. 2000;10:275-7.

19. Laukkarinen J, Nordback I, Mikkonen J, Kärkkäinen P, Sand J. A novel biodegradable biliary stent in the endoscopic treatment of cystic-duct leakage after cholecystectomy. Gastrointest Endosc. 2007;65:1063-8.

\section{Correspondence:}

Conflict of interest: none Financial source: none

Everson Luiz de Almeida Artifon

Rua Guimarães Passos, 260/121

04107-030 São Paulo - SP Brazil

Phone: (55 11)8175-3884

eartifon@hotmail.com

Received: September 10, 2009

Review: November 19, 2009

Accepted: December 11, 2009

\section{How to cite this article}

Artifon ELA, Lopasso FP, Moura GB, Fernandes FAMH, Sakai P, Carrilho FJ, Caldini ETEG, Castro e Silva Junior O. Effects of plastic stenting in commom bile duct of rats. A quantitative reaction analysis using collagen and elastin morphometry. Acta Cir Bras. [serial on the Internet] 2010 Mar-Apr;25(2). Available from URL: http://www.scielo.br/acb 